В.П. Казаков ${ }^{1}$

V.P. Kazakov

\title{
ПЕРЕВОРОТ 1930 Г. И ДИКТАТУРА Х.Ф. УРИБУРУ В АРГЕНТИНЕ
}

\section{THE 1930 COUP AND THE DICTATOR- SHIP OF J.F. URIBURU IN ARGENTINA}

Аннотащия: В статье рассматривается переворот 1930 г. и диктатура Урибуру в Аргентине. Особое внимание уделено конфликту внутри армии, разделенной по идейным убеждениям на две фракции: корпоративистов во главе с генералом Урибуру и либералов во главе с генералом А. Хусто. Корпоративисты или правые националисты боролись против либерально-демократической системы и ратовали за сильное правительство, которое обеспечило бы дисциплину, иерархию и социальный порядок. Это правительство должно быть корпоративистским, опирающимся на «жизненные силы» общества вместо коррумпированных партий. Напротив, группа Хусто стремилась свергнуть правительство радикалов Иригойена, но не ликвидировать конституционный строй. Переворот должен быть военно-гражданским движением, в результате которого появившееся временное правительство должно оставаться у власти лишь до того времени как условия позволят провести выборы. Победила линия Хусто. Урибуру бы вынужден отказаться от своих планов. В Аргентине был восстановлен консервативный режим.

Ключевые слова: Аргентина, переворот 1930 г., диктатура Урибуру, Хусто, Иригойен, радикалы, корпоративистский режим, правые националисты.

${ }^{1}$ Казаков Владимир Петрович - доктор исторических наук. Институт всеобщей истории РАН. Kazakov Vladimir P. - Doctor in History. Institute of World History, RAS. 
Abstract: This article examines the 1930 coup and the dictatorship of Uriburu in Argentina. Special attention is paid to the conflict between military factories divided by ideological conviction: the «corporatists» led by general Uriburu and the «liberals» led by general Justo. The corporatists or right wing nationalists struggled against demoliberal system and advocated a strong government that would maintain discipline, hierarchy and the social order. This government would take the shape of corporatist system, based on the «vital forces» of society instead of the corrupt parties. Он the contrary the Justo faction sought to overthrow the radicals but not to alter the constitutional order. They felt that the coup should be a civilian military movement followed by a provisional government that would remain in power only until conditions necessary for holding national election could be restored. Justo triumphed over Uriburu. After shotrlived dictatorship of Uriburu in Argentina was restored conservative order.

Keywords: Argentina, Uruburu, Irigoyen, Justo, radicals, corporatist system, right wing nationalists

DOI: $10.32608 / 2305-8773-2019-24-1-22-40$

Переворот 1930 г. открыл серию военных переворотов в Аргентине, когда армия непосредственно выходила на политическую авансцену, становилась ключевым элементом политической жизни страны. При этом вооруженные силы выступали не только в качестве репрессивного инструмента, но и как фактор сохранения и модернизации существующей системы.

Переворот 1930 г. был обусловлен целым комплексом, как внутренних, так и внешних причин. К этому времени Аргентина достигла максимального развития в рамках агроэкспортной модели, и обозначался застой в агроэскопортной экономике. Перестали действовать главные источники ее роста: иностранные инвестиции, европейская иммиграция, наличие свободных земель в Пампе. Прямые иностранные капиталовложения в 1914-1931 гг. выросли лишь на 15\% и составили 15\% всех произведенных в 1929 г. инвестиций. Приток иностранных капиталов перестал быть главным двигателем дальнейшего экономического роста. Сократилась иммиграция и как следствие среднегодовой прирост населения упал с 3,8\% в 1895-1914 гг. до 2,3\% в 1912-1928 гг. В результате сокращения среднегодо- 
вых темпов роста аргентинского экспорта с 4,8\% в 1865-1912 гг. до 4,1\% в 1912-1928 гг. Аргентина переместилась с восьмого места в мировой торговле, которое она занимала в 1923 г., на одиннадцатое - в 1929 г. $^{2}$

Закончился период, когда Аргентина могла жить за счет дифференциальной ренты, используя разницу в уровне развития производительных сил в промышленности и сельском хозяйстве. К тому же могущество ее экономической метрополии Англии - клонилось к упадку. Встал вопрос, что делать дальше, каким путем пойдет развитие Аргентины в будущем.

Первой попыткой дать ответ на вставшие перед страной проблемы стала политика лидера радикалов, президента Аргентины в 1916-1922 гг. и 1928-1930 гг. И. Иригойена.

В международных делах она характеризовалась антиимпериализмом, прежде всего антиамериканизмом. Несмотря на давление США и держав Антанты, Иригойен не позволил втянут Аргентину в Первую мировую войну, считая ее империалистической, захватнической ${ }^{3}$. Не был он согласен и с послевоенным порядком, установленном победителями - Версальской системой, которая, по его мнению, была несправедливой и вела к новым войнам. Поэтому Аргентина уже на первой конференции Лиги Наций ушла из нее, когда великие державы не стали даже рассматривать аргентинские предложения по превращению ее в универсальную организацию, объединяющую все страны для сохранения мира и развития сотрудничества между народами, а не в орудие в руках победителей для нового передела мира ${ }^{4}$.

Продолжением этой линии в экономической области стала попытка иригойенистов национализировать нефть и установить государственную нефтяную монополию, как рычаг по выводу страны на путь независимого развития ${ }^{5}$. В социальной сфере активная рабочая политика: признание справедливыми требо-

2 Platt, Tella, 1983. P. 155, 187, 151, 51.

${ }^{3}$ Etchepareborda, 1958. T. IX. P. 99; Zanoni, 1958. T. IX. P. 234; Rock, 1975. P. 149.

${ }^{4}$ Scala, 1958. T. X. P. 26; League of Nations, 1920. P. 90.

${ }^{5}$ Argentina Congreso nacional, 1927. T. III. P. 768, 492, 436, 190, 675. 
вания рабочих по улучшению условий жизни и труда, попытка диалога, а не подавление профсоюзов ${ }^{6}$. Это не относилось к профсоюзам под руководством коммунистов, которые, однако, не имели серьезного влияния в рабочей среде.

Программа реформ Иригойена встретила сильное противодействие со стороны различных политических сил, которое еще больше увеличилось с началом в 1929 г. мирового экономического кризиса. В оппозиции к правительству Иригойена оказались диаметрально противоположные силы: от крайне правых до левых, от консерваторов до коммунистов.

Этому способствовали также действия самих иригойенистов, когда они отказались от соблюдения конституционных норм, когда им стало это невыгодно, и прибегли к насилию. Слухи о подлогах на мартовских выборах 1930 г. в конгресс не были опровергнуты. В атмосфере насилия в сентябре 1929 г. радикалом был убит бывший губернатор Мендосы К.В. Ленсинас, а бывшего губернатора Сан-Хуана А. Кантони держали в тюрьме.

Насильственные действия радикалов стали реакцией на безжалостные атаки оппозиции. В декабре 1929 г. была предпринята попытка покушения на Иригойена. Для борьбы со своими политическими противниками радикальная партия создала специальную организацию «Радикальный клан», состоявший из членов партийных комитетов и правительственных чиновников. Отряды «клана» демонстрировали свою поддержку правительству, нападали на организации оппозиции.

«Эксцессы радикализма» объяснялись ослаблением, как внутрипартийной дисциплины, так и контроля центрального руководства над местными организациями. На эффективность работы правительства и партийного аппарата влиял преклонный возраст Иригойена. Второе президентство лидера радикалов проходило под знаком ухудшения его здоровья. Старый и больной Иригойена уже не мог, как прежде, осуществлять руководство страной и партией.

Среди консерваторов царило единодушие в отношении

${ }^{6}$ Morrone, 1928. P. 113-114. 
необходимости устранения Иригойена. В этом с ними были солидарны независимые социалисты - правое крыло социалистов во главе с Ф. Пинедо, А. Де Томасо, отколовшееся от социалистической партии. Все они пользовались любым поводом, чтобы разжечь ненависть к правительству радикалов и лично к Иригойену. В связи с покушением на Иригойена они его не только не осудили, но обвинили само правительство в создании «преступной атмосферы, в которой живет республика». Де Томасо заявил: «Мы боремся против правительства господина Иригойена, потому что оно действует диктаторски, наносит политический, социальный и экономический вред стране» ${ }^{7}$. Пинедо, охарактеризовав «нынешнее президентство как типичную диктатуру», добавил: «Эта диктатура должна исчезнуть. Необходимо сместить президента Иригоейна, необходимо покончить с президентством Иригойена» ${ }^{8}$. Им вторил В.Д. Этчеверри: «Необходимо покончить с Иполито Иригойеном прежде, чем Иполито Иригойен покончит со страной» ${ }^{9}$.

Непримиримую позицию в отношении правительства Иригойена занимали и левые силы. Социалисты обвиняли президента в установлении личной диктатуры. В одном из выступлений лидер социалистов Э. Дикман сравнил Иригойена с аргентинским диктатором прошлого века Х.М. Росасом «поскольку и тот и другой использовали насилие» ${ }^{10}$.

Если социалисты сравнивали Иригойена с Росасом, то коммунисты проводили параллель между иригойенизмом и итальянским фашизмом (схожесть социальной базы, вождистский характер партии, методы политической борьбы, социальная демагогия $^{11}$.

Однако ни социалисты, ни тем более коммунисты не располагали серьезным весом в политической жизни страны и не были в состоянии оказать серьезное влияние на развернувшиеся в 1930 г. события.

\footnotetext{
${ }^{7}$ Argentina Congreso nacional, 1929.T. III. P. 486.

${ }^{8}$ Ibid., P. 47.

${ }^{9}$ Ibid., P. 496.

${ }^{10}$ La Vanguardia, 30 oct.1929.

${ }^{11}$ La Internacional, 13 jul.1929.
} 
Первоначально политика правой оппозиции - консерваторы, независимые социалисты и антиперсоналисты (отколовшиеся от партии Иригойена радикалы) преследовала цель ослабить и изолировать в результате пропагандисткой кампании в конгрессе и в печати правительство Иригойена, а затем потребовать отставки президента. Пробным камнем стало предложение консервативного депутата А. Виньяна об импичменте Иригойена «за плохое исполнение им своих обязанностей» ${ }^{12}$.

По мере углубления экономического кризиса обострялось и политическое положение в стране. 9 августа 1930 г. блок правых депутатов и независимых социалистов опубликовал манифест 44-х, по числу подписавших его законодателей, в котором заявил о существовании в стране «институционного кризиса», вызванного незаконными действиями правительства, и начале «внепарламентской» борьбы, чтобы дать, «республике конституционное и демократическое правительство» ${ }^{13}$. Спустя десять дней с аналогичным по содержанию заявлением выступили депутаты-антиперсоналисты ${ }^{14}$.

Антикризисные меры правительства Иригойена - отмена конвертируемости песо, инфляционная политика - серьезно затронули интересы господствующих классов. 23 августа в совместном меморандуме Сельскохозяйственное общество, Промышленный союз и Торговая биржа потребовали от правительства значительно сократить государственные расходы, восстановить конвертируемость песо и положить конец его обесценению ${ }^{15}$.

Таким образом оппозиция взяла курс на свержение правительства Иригойена. Идеологами переворота стали правые националисты, группировавшиеся вокруг генерала Х.Ф. Урибуру, вдохновленные идеями праворадикальных, профашистских движений в Европе. Помимо самого Урибуру виднейшими представителями движения были выдающийся аргентинский поэт Л. Лугонес, историки и писатели К. Ибаргурен и

\footnotetext{
12 Argentina Congreso nacional, 1929. T. III. P. 750.

${ }^{13}$ La Nación, 10 ag. 1930.

${ }^{14}$ La Nación, 23 ag. 1930.

15 La Prensa, 23 ag. 1930.
} 
М. Гальвес. Лугонес проделал сложную эволюцию от анархизма и социализма к фашизму. Он мечтал о «новом порядке», создателем которого считал армию. Его речь в Перу в 1924 г. «Время сабли» - развенчивала либерализм, как «мертвую конституционную систему XIX в.», а демократию, как «демагогию». Он апеллировал к «очищающей сабле», которая покончит с «гнилым либерализмом», ослабляющим аргентинскую нацию. Для автора «Войны гаучо» Аргентина могла стать великой нацией, лишь покончив с демократией и прежде всего с всеобщим избирательным правом, настоящим «культом некомпетентности», из которого могло появиться лишь «бездарное правительство» ${ }^{16}$.

Эти идеи получили поддержку в среде националистической молодежи. Трибуной для изложения их взглядов стал еженедельник Nueva Republica под редакцией Э. Паласио и братьев Х. и И. Ирасуста. Наиболее опасным они считали «красную угрозу» и «демагогическую угрозу», под которой они имели в виду политику Иригойена, в частности, в отношении рабочего и профсоюзного движения. Путь борьбы с иригойенизмом им виделся в «хирургической операции», как они называли восстание против лидера радикалов.

По их мнению, недостаточно было свергнуть правительство радикалов, необходимо было заменить всю либеральнодемократическую систему другой - корпоративной, для которой итальянский фашизм представлялся наиболее эффективной моделью. Гальвес писал, что «единственная альтернатива коммунизму в условиях кризиса либеральной системы в Аргентине - это фашизм» ${ }^{17}$. Тирания масс должна быть заменена правительством «наиболее умных и достойных», поддержанных армией «неподвластной коррупции». Новое общество должно строиться на путях фундаментальных принципах: порядок, иерархия и авторитет ${ }^{18}$.

Но представленная ими корпоративная модель не основывалась на массовом движении как классический фашизм, а опира-

\footnotetext{
${ }^{16}$ Lugones, 1962. P. 213.

${ }^{17}$ Цит. по: Navarro Gerroci, 1968. Р. 192.

${ }^{18}$ Ibarguren, 1969. P. 361.
} 
лась на армию, как последний источник иерархического порядка, утерянного при либеральной демократии.

Это не позволяет, по мнению автора, относить их взгляды к классическому фашизму. Этот «креольский фашизм» носил аристократический, элитарный характер и был лишен всякого плебейского налета. Правые националисты провозглашали своей целью покончить с тем, что они называли «преобладанием иригойенистского сброда», «буйством сволочной демократии» ${ }^{19}$.

К 1930 г. в армии образовались две оппозиционные группировки - так называемые «либералы», пользовавшиеся поддержкой консерваторов, антиперсоналистов и независимых социалистов во главе с бывшим военным министром, генералом А. Хусто, - и правые националисты во главе с генералом Урибуру.

Наибольшую активность проявляли последние. Еще в декабре 1928 г. на банкете в честь первой годовщины «Нуэва Республика» Урибуру заявил, «что готов без колебаний встать во главе политического движения, хорошо организованного и с ясными целями, каковы бы ни были угрозы и те последствия, которые повлекли бы за собой его действия» ${ }^{20}$. Заговор в армии стартовал. Урибуру ориентировал своих сторонников на следующие действия: «Чтобы думать о возможности революции, необходимо, прежде всего, создать революционную атмосферу на улице» ${ }^{21}$. В конце 1929 г. для борьбы с радикалами была организована Республиканская лига. Но главным инструментом «революционного возрождения» страны должна была стать армия - единственная здоровая сила в обществе, пораженном «демократическим вирусом» и «демагогией радикалов».

К заговору Урибуру присоединились военные - сторонники генерала Хусто. С самого начала между ними существовали серьезные разногласия. Бывший военный министр хотел лишь свержения Иригойена и лишения его сторонников власти. Урибуру же шел значительно дальше. Он намеревался изменить политический строй, положить конец либеральному государ-

\footnotetext{
19 Подробнее о взглядах правых националистах см.: Rock, 1993. P. 80-82.

${ }^{20}$ Цит. по: Ronquié, 1983. Р. 187.

${ }^{21}$ Ibid.
} 
ству. Генерал был убежден, что со свержением Иригойена ничего не изменится, если не реформировать конституцию и не ограничить избирательное право.

Урибуру планировал заменить представительную систему правления корпоративной, что покончило бы с «господством демагогии» и обеспечило бы «правительство лучших». Его программа включала ликвидацию всех существующих политических партий, включая и оппозиционные к радикалам. Поэтому он отвергал всякое сотрудничество с антииригойенисткой оппозицией, которая могла помешать его планам изменить конституционный строй. Группа Хусто, соглашаясь с необходимостью переворота, отвергала его исключительно военный характер и антилиберальную направленность. По свидетельству подполковника Х.M. Саробе, ближайшего сотрудника Хусто и связного между ним и Урибуру, цель выступления Хусто выразил следующими словами: «С оружием в руках выйти на конституционный путь и на этой основе как можно быстрее вернуться к нормальному положению» ${ }^{22}$.

Разногласия касались также состава временного правительства и его продолжительности. Урибуру претендовал на пост президента и намеревался составить свой кабинет из людей, не связанных с политическими партиями. Главной задачей временного правительства должны были стать изменения конституции, отмена закона Саенса Пеньи о всеобщем избирательном праве, введение корпоративной системы. Для осуществления своей программы Урибубу требовал пятилетней диктатуры.

План Саробе, одобренный Хусто, напротив, предполагал гражданский характер временного правительства во главе с вице-президентом сената антиперсаналистом Л.Д. Этчеборде и скорейшее проведение выборов ${ }^{23}$.

Вопреки утверждению заговорщиков, армия в целом не была на их стороне. В августе 1930 г. Урибуру и его ближайшие сотрудники должны были признать печальную для себя реальность: ни одна воинская часть столичного гарнизона или Кампо

22 Sarobe, 1957. P. 21.

${ }^{23}$ Ibid. P. 37. 
де Майо, военного лагеря около Буэнос-Айреса, не поддерживала заговор. Большую часть заговорщиков составляли отставные военные или те на действительной службе, кто не командовал соединениями. Для Урибуру стала очевидной невозможность чисто военного переворота, и ему пришлось обратиться за поддержкой к оппозиционным партиям.

Военный министр Л. Делепиане знал о заговоре и постарался убедить Иригойена действовать и арестовать заговорщиков, но безрезультатно, и 2 сентября подал в отставку.

Иригойен предпочел розовую версию, которую рисовал ему вице-президент Э. Мартинес. Президент был убежден, что его популярность в народе достаточна, чтобы преодолеть все трудности. Положение в стране не было серьезно проанализировано радикалами. Вместо этого различные фракции внутри партии и правительства стали плести интриги, которые сводились к следующему: чтобы преодолеть кризис и удержаться у власти необходимо сместить Иригойена.

Одновременно с армейским заговором в правительстве возникли и две группировки: Э. Мартинеса - Е. Гонсалеса - по имени вице-президента и министра внутренних дел - и О. Ойанарте - министра иностранных дел. Обе они боролись за место наследника Иригойена. В среде военных заговорщиков на вицепрезидента указывали как на главу возможного дворцового переворота, который установил контакты с Урибуру. Урибуру удалось убедить Мартинеса, что с низложением Иригойена тот займет его место. Не в этом ли кроется причина бездействия правительства в день переворота?

5 сентября Иригойен в связи с болезнью передал свои полномочия вице-президенту. Однако накануне переворота борьба в правительстве радикалов не закончилась победой ни одной из фракций $^{24}$.

Выступление началось утром 6 сентября. Ничто, казалось, не обещало мятежникам успеха. Кампо де Майо не желал восставать. Командующий гарнизоном генерал А. Альварес был сторонником правительства. Столпившихся у ворот граждан-

${ }^{24}$ Mayo, 1983. P. 147-150. 
ских, среди которых находились депутаты-консерваторы и руководители независимой социалистической партии, не пустили в лагерь. В столице первая армейская дивизия и полиция подчинялись приказам правительства. Военно-морской флот выжидал.

Такая оппозиция армии ясно показывала низкую степень популярности мятежников, лояльность офицеров правительству и малую вероятность успеха переворота. Утро 6 сентября обнаружило, что план военного восстания был не осуществлен из-за отсутствия бойцов. Урибуру оставалось только попытаться поднять Колехио Милитар и получить поддержку со стороны оппозиции.

Директор Колехио Милитар полковник Ф. Рейнольдс, несмотря на свою приверженность радикалам, присоединился к мятежникам. В тот момент, он считал, что Иригойена необходимо убрать, так как он болен и является пленником своего окружения. Рейнольдс обещал поддержку Колехио Милитар, не посоветовавшись с офицерами. Однако старшие офицеры отказались присоединиться к движению. Они мотивировали свой отказ тем, что с передачей Иригойеном своих полномочий вице-президенту и предстоящей реорганизацией правительства будет достигнуто разумное решение стоящих перед страной проблем, единственный причиной которых, по утверждению заговорщиков, является президент, и что не нужно идти на опасную для страны авантюру с единственной целью свергнуть человека, который уже не правил.

Наоборот, младшие офицеры с энтузиазмом приняли предложение принять участие в перевороте. К ним присоединились кадеты, за исключением тех, чьи родители были в правительственном лагере.

Урибуру распределил оружие среди собравшихся у Колехио Милитар гражданских лиц и во главе колонны в 1,5 тыс. человек начал «марш на Буэнос-Айрес». В его распоряжении было 600 кадетов и офицеров Колехио Милитар и подразделения школы связи в 800 человек. К ним присоединились гражданские лица, чья численность увеличивалась по мере приближения восставших к столице. В то же время несколько самолетов 
с воздушной базы Паламар разбрасывали листовки с призывом к населению присоединиться к восставшим. Последние, не встречая сопротивления кроме перестрелки на площади конгресса, беспрепятственно вошли в президентский дворец Каса Росада и добились отставки Э. Мартинеса. 7 сентября, находившийся в Ла-Плате Иригойен также подписал свою отставку. По словам участника переворота капитана Х.Д. Перона, успех движения казался чудом ${ }^{25}$. Но у этого «чуда» имелось весьма рациональное объяснение: к моменту переворота радикализм охватил глубокий кризис.

Придя к власти, став временным президентом, Верховный суд признал его правительство де-факто, Урибуру распустил национальный конгресс, сместил власти почти всех провинций, за исключением тех, где власть принадлежала антииригойенистской оппозиции, ввел осадное положение на всей территории страны, которое действовало в течение всего его правления. Страна, не знавшая смертной казни с момента падения диктатуры X.M. Росаса в середине XIX в., вновь ее получила. Ряд анархистов были казнены. Анархистские и коммунистические профсоюзы подверглись разгрому. Сотни иностранцев, которых режим считал подозрительными, в соответствии с законом о местожительстве были депортированы. Преследовались также некоммунистические организации: закрывались оппозиционные газеты, а их редакторы подвергались тюремному заключению, была создана специальная секция полиции по борьбе с коммунизмом. В помощь армии сформирован Гражданский легион - частная военная организация, членам которой гарантировалось военное обучение, снабжение оружием и разрешалось вмешательство «в защиту общественного порядка». В прямом насилии в отношении рабочего и демократического движения режим Урибуру видел наилучшую политику.

В состав временного правительства вошли предприниматели и крупные собственники, тесно связанные с иностранным капиталом. Секретарь Урибуру Э. Кинкелин был главным акционером компании, носившей его имя, и представлял интересы

${ }^{25}$ Sarobe, 1957. P. 310. 
немецкого концерна Стинненс. Ведущий экономист страны А. Бунхе, который после переворота стал министром финансов «временного губернатора» провинции Санта-Фе являлся членом административного совета Андской нефтяной корпорации. Министр общественных работ О.С. Пико возглавлял две нефтяные компании: Аргентинскую компанию КомодороРивадавии и Андскую нефтяную. Акционером и членом административного света первой из них был министр сельского хозяйства О. Беккер Варела, который также представлял интересы «Вест Индиан $\mathrm{K}^{0}$ » - филиала Стандарт Ойл. Министр иностранных дел Е. Боги являлся президентом Промышленной и Торговой нефтяной компании - филиала Англо-Першиан. Министр внутренних дел М. Санчес Сорондо был адвокатом Стандарт Ойл ${ }^{26}$.

С нефтяным бизнесом была связана также семья Урибуру, принадлежавшая к олигархии провинции Сальта. Его двоюродный брат служил адвокатом Стандарт Ойл. Сам Урибуру и его сын стали акционерами учрежденной после переворота торговой компании - филиала «Иностранных предприятий» занимавшегося импортом нефти. Неудивительно поэтому, что правительство Урибуру отложило на неопределенное время национализацию нефти и подтвердило все предоставленные ранее Стандарт Ойл концессии Фраза журналиста Вальдо Франко, что «переворот пахнет нефтью» прочно утвердилась в литературе при характеристике переворота Урибуру.

Режим Урибуру в силу недолгого пребывания у власти не выработал цельной экономической стратегии. Однако внутри страны была социальная сила, симпатизировавшая идеям диктатора. Не случайно, что первым, кто пришел в Каса Росада поздравить Урибуру с победой, был президент Промышленного союза А. Коломбо.

Промышленники поддержали Урибуру, поскольку выступали против «демократической демагогии радикалов», резко отрицательно относились к социальной политике Иригойена, так как его рабочее законодательство, по их мнению, удорожало

${ }^{26}$ Rouquié, 1983. P. 215. 
производство, делало неконкурентоспособной аргентинскую продукции на внешнем рынке.

Резко отрицательно они относились и к существовавшей партийно-политической системе, которая не учитывала их интересов. Парламент превратился в орган, который не представлял «жизненные силы страны», занимался «индустрией политики» вместо политики индустриализации. Поэтому промышленники были солидарны с планами Урибуру по установлению корпоративного строя, который, по их мнению, делал возможным совместные действия властей и предпринимателей и должен был преследовать две главные цели: 1) Расширять связи с США и 2) развивать национальную промышленность ${ }^{27}$.

Таким образом, по мнению Промышленного союза, за политическими изменениями должны была последовать не менее серьезные социально-экономические, суть которых идеолог Промышленного союза и ведущий аргентинский экономист А. Бунхе выразил в следующих словах: «Мы должны убедить себя, сеньоры, что нынешнее поколение является последним поколением импортеров и эстансьеро. В следующем поколении, поколении наших детей, будут преобладать фермеры и промышленники» $^{28}$.

Исторически являясь противниками свободной торговли и выступая за протекционизм, промышленники никогда не выступали против присутствия иностранного капитала в национальной экономике, ограничивая свою критику лишь внешнеторговой зависимостью Аргентины от промышленно развитых стран. Неприятие антиимпериализма прежде всего антиамериканизма, Промышленным союзом вытекало из разного понимания им и иригойенистами роли США в развитии Аргентины. Для иригойенистов экспансия американского капитала, прежде всего в нефтяной области, являлась препятствием для независимого развития Аргентины. Напротив, для промышленников главной опорой. В США они видели источник инвестиций, новых технологий. Ориентация на США объяснялась также тем,

27 Nueva Historia Argentina, 2000. P. 204-207, 224.

${ }^{28}$ Цит. по: Llach, 1985. Р. 13. 
что экономические связи с Англией исчерпали себя.

Поэтому Промышленный союз решительно выступил против национализации уже действовавших иностранных компаний. Его план заключался в создании смешанных компаний, где наряду с иностранным капиталом смог бы действовать и аргентинский, что, по мнению, Коломбо, обеспечило бы промышленное будущее страны, так же, как и ее «экономическую и политическую независимость». Критикуя нефтяную политику Иригойена, Бунхе считал, что «нам абсолютно необходимо освободиться от импорта иностранной нефти», но утверждал, что государственная нефтяная монополия никогда не позволит этого достигнуть, что необходимы частные инвестиции ${ }^{29}$.

Трудно сказать, насколько Урибуру проникся этими идеями, но его ориентация на США проявилась в первые же дни пребывания у власти. Уже 9 сентября в интервью американскому корреспонденту Урибуру заявил, что Аргентина готова сотрудничать с США и участвовать в панамериканских конгрессах. На следующий день в телефонном заявлении «Нью Йорк Таймс» он объявил, что его правительство незамедлительно назначит посла в Вашингтон (в годы второго президентства Иригойена, это пост оставался вакантным. - B.K. $)^{30}$. В США свержение Иригойнена было воспринято как доброе предзнаменование. Сообщая о его падении, «Нью Йорк Таймс» писала: «Иригойен выступал против планов Соединенных Штатов. Вашингтон ожидает от нового политического режима большего сотрудничества. Аргентинский президент (Иригойен. - B.K.) отказался назначить сюда посла. Он боролся против доктрины Монро» ${ }^{31}$.

Еще более ясно выразился о событиях в Аргентине журнал Fortune: «Последняя революция свергла Иригойена - фанатичного крестоносца против всего американского, включая нефтяные компании. Это он, кто заставил правительство вмешаться в продажу бензина и кто, снизив цены и манипулируя продажами, захватил 22\% всех продаж. Его низложение усиливает позиции Стандарт Ойл в Аргентине».

\footnotetext{
${ }^{29}$ Solberg, 1979. P. 127, 122, 143.

${ }^{30}$ Mayo, Garcia, 1983. P. 161.

${ }^{31}$ Ibid. P. 158.
} 
«Ойл энд Гэс Джорнел», со своей стороны, указывал: «[...] ожидается, что последние политические потрясения в Аргентине скажутся благотворно на действующих в стране иностранных нефтяных компаниях ${ }^{32}$

Американская торговая палата в Аргентине просила Вашингтон о скорейшем признании временного правительства. Кроме того, она предложила ему займ в 10 млн песо ${ }^{33}$.

Для США правительство Урибуру являлось гарантией того, что американские интересы в стране будут уважаться и Аргентина вернется в орбиту панамериканизма. Поэтому уже 18 сентября США признали временное правительство Урибуру ${ }^{34}$.

Переворот Урибуру стал и проявлением англо-американских противоречий. Впервые США получили шанс серьезно потеснить английский капитал и занять лидирующие позиции в новых отраслях экономики, связанных с промышленным развитием Аргентины.

Но международное значение переворота Урибуру не ограничивалось рамками межимпериалистических противоречий. Внешняя политика Иригойена (активный нейтралитет в годы Первой мировой войны, попытка создать блок неприсоединившихся к войне латиноамериканских государств, неприятие Версальской системы и как следствие - выход из Лиги Наций) свидетельствовала о его стремлениях не быть в политической системе империализма, а попытка национализировать нефть и создать государственную нефтяную монополию - занять самостоятельное место в мировом капиталистическом хозяйстве.

Но разве все это не свидетельствовало о зарождении третьей позиции - помимо социализма и империализма - в международных, в том числе экономических, отношениях? Особенно показателен вопрос о нефти, поскольку от советской позиции зависела сама возможность национализации нефти. В случае бойкота со стороны английских и американских компаний, СССР обязывался поставить всю недостающую нефть в обмен на аргентинскую сельскохозяйственную продукцию. То есть на

\footnotetext{
${ }^{32}$ Ibid. P. 156

${ }^{33}$ Ibid. P. 155.

${ }^{34}$ Ibid. P. 169.
} 
основе клиринга, что исключало зависимость от мировых валют и могло стать зарождением нового мирового экономического порядка, о необходимости которого говорил министра иностранных дел Аргентины О. Пуэйрредон на первой конференции Лиги Наций в ноябре 1920 г., прежде чем уйти с нее. В непосредственном товарообмене он видел пути покончить с господством в мировой торговле международных трестов.

Таким образом, в аргентинской позиции берет начало теперешняя тенденция, которая проявилась в полной мере уже после Второй мировой войны: торговля стран третьего мира с СССР была не просто необходима, но и могла стать инструментом для достижения ими экономической самостоятельности.

В Аргентине реализация этой политики шла через Южамторг - акционерная компания по торговле с Южной Америкой. После ее создания в 1927 г. Пуэйерредон стал ее главным юрисконсультом.

После прихода к власти, у Урибуру появилась прекрасная возможность подтвердить свои антикоммунистические заявления практическим делами. В июле 1931 г. Южамторг был разгромлен аргентинской полицией, к его сотрудникам были применены меры физического воздействия.

В свете вышесказанного переворот Урибуру имел и мировое значение: он предстает, как попытка пресечь появление третьей силы, помимо социализма и империализма, в мировой политике.

Возвращаясь к положению Аргентины в 1930-1931 гг. следует отметить, что в среде господствующей социальной силы землевладельческой олигархии - планы Урибуру по созданию корпоративистского государства не пользовались симпатией. Да и менять Англию на США в качестве нового хозяина, она не хотела и не могла, так как на мировом сельскохозяйственном рынке Аргентина и США были конкурентами.

Выразителем интересов олигархии был Хусто. Как говорилось выше, целью Хусто и стоящих за его спиной политических сил являлась не замена представительного режима корпоративным, а свержение Иригойена. Политическая линия Хусто состояла в сохранении видимости представительной демократии 
при фактической ликвидации ее главного элемента - свободных выборов. После недолгой борьбы Урибуру был вынужден отказаться от своих планов и назначить на ноябрь 1931 г. президентские выборы. Проходившие в условиях открытого террора, подлогов и недопущения кандидатов от радикальной партии, они принесли победу Хусто, который в феврале 1932 г. занял президентское кресло.

Аргентина вступила в период, который вошел в ее историю, как «позорное десятилетие»: время реставрации порядков, царивших до принятия закона Саенса Пеньи и прихода радикалов к власти.

В международных делах возобладала ориентация на Англию, свидетельством чего явилось заключение в мае 1933 г. крайне невыгодного для Аргентины соглашения с Великобританией, известного как пакт Рока - Ренсимен. Вплоть до конца Второй мировой войны Аргентина оставалась в стерлинговой зоне.

\section{БИБЛИОГРАФИЯ/REFERENCES}

Argentina Congreso nacional. Cámara de diputados: 1927. T. III. Buenos Aires, 1927.

Etchepareborda R. La neutralidad y la presión belicista // Hipólito Yrigoyen. Pueblo y Gobierno. T. I-XII. Buenos Aires, 1958. T. IX.

Nueva Historia Argentina / Falcon R. (dir.) T. 6. Buenos Aires: Sudamerica, 2000.

Ibarguren $C$. La historia que he vivido. Buenos Aires: Sudamericana, 1969.

League of Nations. The records of the first assembly. Plenary meetings. Geneva, 1920.

Llach J. Argentina que no fue. Buenos Aires, 1985.

Lugones L. La Grande Argentina. Buenos Aires, 1962.

Mayo C.A., García F. La diplomacia del petróleo (1916-1930). Buenos Aires, 1983.

Morrone A. El derecho obrero y el presidente Yrigoyen. Buenos Aires, 1928. 
Navarro Gerrosi M. Las nacionalistas. Buenos Aires, 1968.

Platt D.C., Tella G. Di. Argentina, Australia and Canada. Studies in comparative development. 1870-1965. Oxford Univ. Press, 1983.

Perón J. Lo que yo vi de la preparación y realización de la revolución del 6 septiembre de 1930 // Sarobe J.M. Memorias sobre la revolución del de septiembre de 1930. Buenos Aires, 1957.

Rock D. Authoritarian Argentina. Berkley, 1993.

Rock D. Politics in Argentina 1890-1930. The Rise and fall of Radicalism. Cambridge Univ. Press, 1975.

Ronquié A. Poder militar y sociedad política en la Argentina. Buenos Aires, 1983.

Sarobe J.M. Memorias sobre la revolución del 6 septiembre de 1930. Buenos Aires, 1957.

Scala J.N. Hipólito Yrigoyen y la sociedad de naciones // Hipólito Yrigoyen. Pueblo y Gobierno. T. I-XII. Buenos Aires, 1958. T. $\mathrm{X}$.

Solberg C. Oil and nationalism in Argentina. Stanford: Stanford Univ. Press, 1979.

Zanoni E.P. Yrigoyen y la diplomacia aliada // Hipólito Yrigoyen. Pueblo y Gobierno. T. I-XII. Buenos Aires, 1958. T. IX. 